\title{
BEEF PRODUCTION IN SOUTH WESTLAND
}

\author{
J. S. SUlLtvan
}

Farmer, Fox Glacier, South Westland

\section{Abstract}

An outline of the policy for fattening beef cattle on a Fox Glacier farm showing the progress and development over 20 years is pre sented, along with the methods of feeding and fertilizing needed to maintain a high standard of beef production in a climate which is common only to Westland.

\section{INTRODUCTION}

Beef production has been the life-blood of farming in South Westland since the land was first settled nearly 100 years ago, and fortunately the early settlers were most particular to establish good breeding herds. This policy, I am pleased to say, has been carried on to the present day.

South Westland has no large areas of farm land common to other provinces, but consists of a series of river valleys 16 to 30 $\mathrm{km}$ apart, varying in size from 4000 to 16000 ha. Soil fertility differs from glacialfed river deposits (predominantly greywacke) to mica schist from the smaller mountain streams. By Westland standards the latter is very fertile and responds well to cultivation and topdressing and will support good pasture under normal weather conditions for at least 20 years.

South Westland climate is relatively mild, with a high rainfall and no extremes of heat or cold. Maximum temperatures rarely exceed $25^{\circ} \mathrm{C}$ and seldom fall below $10^{\circ} \mathrm{C}$. Frosts normally begin in early June and may continue intermittently through until October. A heavy frost is $-4^{\circ} \mathrm{C}$ and wind is almost non-existent. Height above sea level is about $110 \mathrm{~m}$. Average rainfall is 4250 $\mathrm{mm}$, but in exceptionally wet years it has been as high as 6000 $\mathrm{mm}$. In spite of the high rainfall, the area has quite a lot of pleasant sunny weather.

My farm at Fox Glacier, a 3-hour drive from Greymouth, consists of 570 ha of relatively flat land which varies from fertile 
deep silt to rough river deposit of gravel and large stones, and about 30 ha of native bush. The farm is in three separate blocks of almost equal size but differing in formation. Soils are mainly gley recent soils of the Hari Hari set plus a smaller area of recent soils belonging to the Hokitika set.

I also have a sixth share in a temporary grazing lease which has a total area of 2300 ha. Approximately 1000 ha is grazable and is commonly used for sheep and store cattle in the summer months and in the winter lessees graze equal numbers of cows.

Originally the farm was part of a family partnership, and in 1957 when I took it over, there were only six paddocks ranging from 24 ha to 168 ha and fences were very substandard. Stock numbers were 90 breeding cows and approximately 180 dry cattle from yearlings to 3 -year-olds. There were also about 450 sheep including 400 ewes.

From 1957 to 1968 I worked the property on my own apart from some casual labour for seasonal work and a fair measure of help from my wife. Since 1968 my brother-in-law has worked with me and we have been able to increase the production of the property markedly over the last twelve years.

The farm has now been subdivided into 34 paddocks and about 200 ha have been cultivated and sown in improved pasture. Cultivation first commenced in 1958, and since then a new paddock has been sown each year and has varied in size from 6 to 20 ha.

The cultivation programme has been to plough or giant disc and sow a crop of swedes and turnips for winter feed. After the crop has been grazed off the ground is cultivated again and sown in permanent pasture, preferably about November-December, but weather conditions are a crucial factor. The pasture mixture has remained much the same over the years and consists of $3 \mathrm{~kg}$ of Huia white clover, $2.25 \mathrm{~kg}$ of Hamua red clover, $2.25 \mathrm{~kg}$ of Kahu timothy, $4.5 \mathrm{~kg}$ of Apanui cocksfoot, $18 \mathrm{~kg}$ of a mixture of Ruanui perennial ryegrass and Manawa ryegrass.

Stock numbers are now 958, made up of 270 cows, 278 rising 2-year-old cattle, 403 calves and 7 bulls. All the sheep were sold in 1968, but in recent years 300 wether lambs are purchased each year for the control of ragwort.

\section{PRODUCTION POLICY}

Prior to 1963, cattle were not fattened until 3 years old. With the establishment of some better pasture and quite a bit of sub- 
division, the change was made to produce prime beef at 16 months to 2 years old. Annual turnover has now reached 460 head, although this number was down for the year just ended 30 April, owing to the very bad season. Approximately 220 calves are reared each year but with cow numbers up this year we hope to have about 250. Calf purchases vary from 200 to 260 according to the number of 18-month-old cattle on hand.

My policy is to buy all steer calves, about $50 \%$ of them being top lines and the balance medium to small. The purpose of this is to have cattle to carry through to 2 years old rather than have to buy store 18-month-old steers which are usually priced out of all proportion to the fat cattle schedule. When buying calves I usually look for size and length rather than condition, and prefer Hereford or Hereford cross.

My own calves are nearly all Herefords, and calving begins in early August and continues through until late October, with most of the calves being born before the end of September.

All calves are drenched and treated for lice at weaning in early May, and bought calves receive the same treatment when they arrive on the farm. Only those that show signs of worms are drenched again and the number would rarely exceed 4 or $5 \%$.

The policy is to fatten as many steers and heifers as possible at 18 months and to carry the remainder through until 2 years old. To achieve this, the best calves are drafted off shortly after weaning in May and are break-fed on autumn-saved pasture. For the first six weeks they are given breaks of 1 to 3 ha according to numbers and then reduced to smaller breaks, receiving a fresh area about every three days. On frosty mornings they are fed one bale of hay to 30 head. When the autumn-saved pasture is finished, usually near the end of August, the yearlings are then set-stocked at 3 to the hectare in the paddocks they have just strip-grazed and remain there until they are sold in late February to mid-March. In a normal year, the 18-month steers will average $270 \mathrm{~kg}$ with the top 40 often reaching weights of $295 \mathrm{~kg}$. Allowing that the steers are about $160 \mathrm{~kg}$ when set-stocking commences, this represents a production gain of $330 \mathrm{~kg} / \mathrm{ha}$ over a period of 7 months.

The remaining rising 2-year-old steers are wintered on the swede crop for most of June, July and August and then return to paddocks which were grazed off in the early winter. They are stocked at $2 \frac{1}{2}$ to the hectare, and are usually ready for the market during December-January. 


\section{FERTILIZER PROGRAMME}

Prior to sowing grass seed, lime at $5 \mathrm{t} / \mathrm{ha}$ and superphosphate at $500 \mathrm{~kg} / \mathrm{ha}$ are applied, with maintenance dressings of 250 $\mathrm{kg} / \mathrm{ha}$ of superphosphate in the spring and $250 \mathrm{~kg} / \mathrm{ha}$ of $30 \%$ potassic superphosphate in February. After the initial dressing, lime is applied at $2.5 \mathrm{t} / \mathrm{ha}$ every five or six years. In late April, 5 tonnes of ammonium sulphate is applied to selected paddocks at the rate of $125 \mathrm{~kg} / \mathrm{ha}$ for winter grass. This practice has proved most successful and I feel it is probably the cheapest winter feed available.

With our heavy rainfall and the porous nature of the ground, leaching is quite severe and it is essential to apply fertlizer every year or pasture will revert very rapidly.

\section{HA Y}

Normally about 2500 or 3000 bales of hay are made in late January and February. An average yield is 200 bales/ha from pasture closed for seven to eight weeks. Feeding usually commences about mid-June and finishes when the hay runs out about midOctober, by which time only cows with calves at foot are being fed. Only in the last two years has hay been purchased owing to the very wet seasons. Freight charges make it very expensive to buy, with the lowest back-load rate being 90 cents per bale.

\section{MARKETS}

The markets for beef have been restricted to established freezing companies in Canterbury and the Addington markets, plus a small local trade of about 100 head per week, formerly killed at Hokitika and now at Kokiri. In latter years there has been some buyer interest from Otago and Southland, but usually only when the market is buoyant. The recent construction of a producers' own meat-packing plant at Kokiri should prove most beneficial.

Whataroa is the only close market for purchasing store cattle. Stock numbers through these yards have risen steadily over the years, but regular sales are only held in October and March for adult cattle, with three calf sales in April. Calf numbers have shown the most dramatic rise. The first sale was held in 1960 with less than 200 head on offer; now about 2500 calves are auctioned annually and keenly sought after by buyers from all parts of Westland. 


\section{ECONOMICS}

Tables 1 and 2 give an indication of the costs involved in farming at Fox Glacier and how these costs have escalated, particularly over the past two years.

TABLE 1: CHANGE IN LIME AND FERTILIZER COSTS AT THE FARM OVER THE PAST 20 YEARS

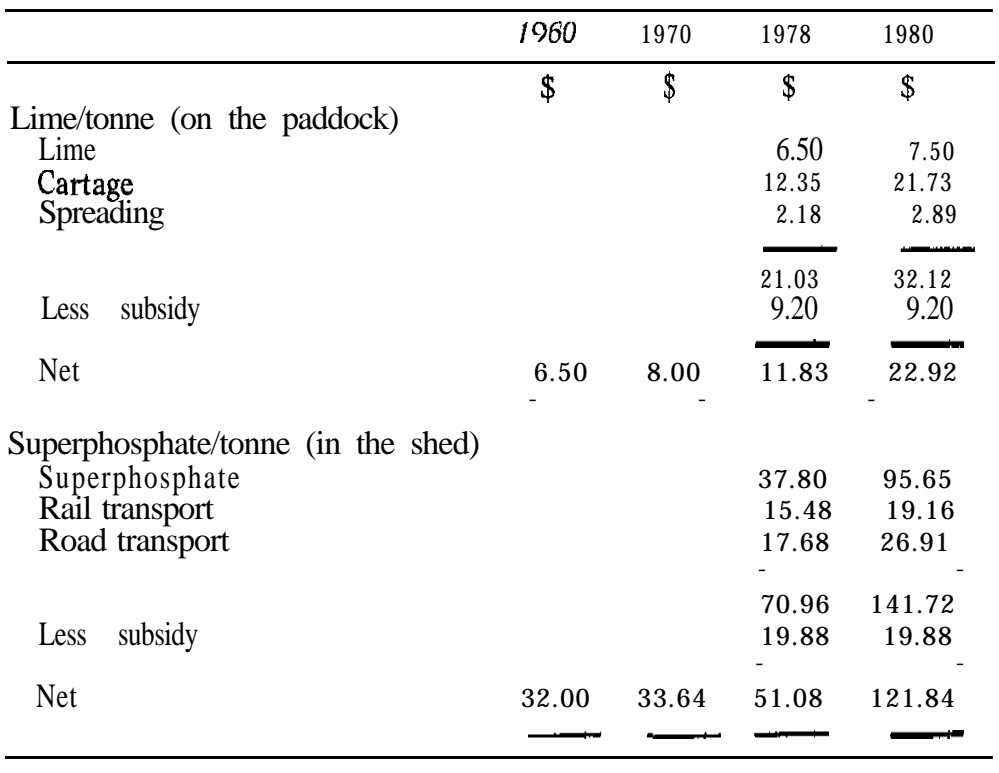

TABLE 2: FREIGHT COSTS AND FAT STEER PRICES OVER THE PAST 20 YEARS

\begin{tabular}{lccccc}
\hline & 1960 & 1970 & 1973 & 197.5 & 1980 \\
\hline $\begin{array}{l}\text { Freight cost/head: } \\
\text { To nearest port works }\end{array}$ & $\$ 8.30$ & 8.50 & 9.14 & 10.29 & $\mathbf{\$}$ \\
$\begin{array}{l}\text { Fox Glacier to Ross } \\
\text { (railhead) }\end{array}$ & & & & & 12.92 \\
$\quad \begin{array}{l}\text { Ross to Addington } \\
\text { Fox Glacier to Kokiri }\end{array}$ & & & & & 20.07 \\
$\begin{array}{l}\text { 18-month Fat Steer } \\
\text { prices/head (gross) }\end{array}$ & 110.00 & 130.00 & 191.00 & 93.30 & 270.00 \\
\hline
\end{tabular}


Advantages for beef farming in South Westland are: A relatively mild climate and good soil type

Good autumn pasture growth, usually extending into late May A free-draining soil and flooding of farm land by rivers is very rare

Very little pasture damage caused by insects

Stock health is good with $\mathrm{Tb}$ and brucellosis almost non-existent

All combine to make ideal conditions for beef production, and a good place to live.

Disadvantages are:

Spring growth can be very late and sometimes non-existent

Bank erosion from fast flowing rivers

Long wet periods make it difficult to employ permanent staff

Unavailability of store stock except in autumn

Distance from markets both for buying and selling

High freight costs on stock and essential goods

The violent fluctuations in beef prices, with ever-increasing freight charges and other costs make future planning very difficult.

These things aside, I consider there will always be a place for the production of beef cattle in South Westland, and I think the industry will continue to expand for the following reasons. There are still large areas of land awaiting development; the construction of a producer-owned meat packing plant at Kokiri should stimulate growth in cattle numbers; a younger generation of farmers with progressive ideas are taking over the land.

The opportunity is still there for the young man who has the will to work, to live in an area which is distant from the amenities offered in towns, and the ability to subdue his bank manager during adverse seasons.

Looking back over the last 23 years one must ask the question: has it all been worth while? I feel that it has, because apart from now having a valuable asset one gets immense satisfaction improving the productivity of the land. 